\title{
LOCAL WISDOM: THE VALUES SYSTEM OF MINANGKABAU ETHNIC CUSTOMS AS A FUNDAMENTAL BASIC OF EDUCATIONAL CHARACTER IN INDONESIA
}

Jurnal Pendidikan Luar Sekolah

http://kolokium.ppj.unp.ac.id/ Jurusan Pendidikan Luar Sekolah

Fakultas Ilmu Pendidikan

Universitas Negeri Padang

Sumatera Barat, Indonesia

Volume 6, Nomor 2, Oktober 2018 DOI: 10.5281 /zenodo. 1471725

\author{
Najibah Taher', \\ 1Jurusan Pendidikan Luar Sekolah Fakultas Ilmu Pendidikan Universitas Negeri Padang \\ 2Email: najibahtaher@gmail.com
}

\begin{abstract}
The function of National Education system has to build and develop the human character and personality in civilization of Indonesian based on the potentiality of the nature of Indonesian people. Indonesian people must behave in the good personality as a nation among the people in the world. Each citizen of The Republic of Indonesia must behave in a good personality: they have must be religious, deligent, clever, discipline, brave, have a point of view, broad minded, discipline, can develop mind set, good attitude, have adversity, pleasant, human dignity, appreciate, honestly, human dignity and other virtues. One of the aspects influence of shaping human character is the values system of our community. In west Sumatera (Ethnic of Minangkabau\} has specially values which is different of other community dealing with shapping character or personalty. Education system must be responsibility to educate people in shaping a good character as a fundamental of educational system. In this occasion I would like to discussion in dealing with the basic aspect of implementing of educational character in our system must be based on the value system of the community or society.
\end{abstract}

Keywords: Local Wisdom, Knowing Value System, Custom of Minangkabau, Fundamental Basic of Education, Character

\section{BACKGROUND}

The ideal concept of educational in Indonesia based on Undang-Undang No. 20 Th 2003 about National Educational System say that educational is the activities tha realized to make clintle educate people or young generation to be a good citizent Which are smart, clever, have a good science, believe in God, havea good personality, moral and, human dignity and can develop their potentiality for competitiveness in a global and plural society .

The function of National Education is to shape and develop the individual character or good personality, civilized and human dignity and smart citizent which is aim to develop people believe in One God, healhthy, wise, capacity, creative, well citizenship and democratic society and responsible (Dronkers, Karsten, Velden, Webbink, \& Werfhorst, 2011).

To build a strong country we must have making preparation by educate people through educational character and culture activities both of them are jointly together. In this 
case we can do it by performing the values system and culture in the community of Minangkabau West Sumatera.

Based on social fenomena in this country more than one decade the social life in Indonesia especially in human relation often accured conflict among the ethnic groups or between student's group and the others. Not just like that, also heppened in other social life between one community and the other community more than a conflict situatin we can see among the political leader, as far as are also influes the economic system and trade. It can be seen in everyday life everywhere and every place; at home, office, school almost in a very aspect of social life. Some people even though he or she is a teenager or adult some time they making disturb to each other and make a noice they become unpolite, they don't care. There are others so many fenomenon that people who act unpolite tha can make human dignity is gong down. Based on these fenomena and accured in the community, It can be concluded that some of the people in our community have low character and moral development is going down. So what is the solution to overcome the problem....?.

\section{PROBLEM}

By looking several fenomena a head wecan see the problem it is not just come from lack of the educational system only, but they come from of many aspects of social life in the commutity (Minkler, 2012). There are many aspects can influence the bad character and social conflicts in our society, there are; economic problem, abuse, lack of education, understanding and the application of religion and social custom as far as how to implentation the social regulation and government policy in several aspects of social life. Some of people to improve their quality of life by doing in negative way. Because of that the human character in Indonesia are not determine the positive value which determine by their own culture as a good citizen.

More over the development of globalization with advancing science and technology especially in informatica and communication have changed the way of life of the people in community (Tchuente, 2006). The world change to day has many impact for community life either positive or negative. It's also change the way of thinking, the way how to fulfill the human need either psychologically and phycically. There are a different way of thinking beween educate people and uneducated people, between the poor and the have.

According to the above so the problem is how to, “The Local Wisdom: The Values System and Custom can be Implemented in Educational Character and Culture Through Non Formal Educational System“.

\section{PURPOSE}

This paper is purposes for:

1) To create an enthuastic and generate the idea and positive thingking among the educator community leader, formal and informal leader and as well as the people who concern with educational problem.

2) To gather information, aspirations, idea, and opinions from experts, government leader, non formal leader, or key persons leader in the commnunity, instructure or academic 
Local Wisdom: The Values System of Minangkabau Ethnic Customs...

staff in highire education, practical and the people who concern with educational activities to get new alternative as solution to approach educational character by implementing "Local Wisdom: the Values System of Minangkabau ethnic Custom As A Fundamental Basic of Educational Character and cultur in Indonesia.

There is an expression of Minangkabau culture: "Kato mufakat, sakato urang sadonyo, elok safaham sahakikat santoso kito salamonyo". It means that say together as unity, all together with the agreement, good understanding for one idea, so it will be welfere for ever. One opinion in one action, one purpose will result in happiness for every one in society. Commonly Minangkabau peole like an harmonism, harmony among the people and family, harmony to the nature and well response to other opinion.

\section{DISCUSSION}

\section{Definition of Charater}

Character is a unic of personality which relatively stability in the individuals as fundamental basic of individual performancein behavior at a high level of norm standard. According to Prayitno (2010) said the indicators of character there are several aspects of behavior; master of self; discipline, hard work and difensive, responsibility, fair, truthly, fine, good heart, obidient, polite and nicely, loyality, democratic, sharing together, work hand in hand and discussion together, tolerance, everything in order, feaceful, consistent (Centre for Strategy \& Evaluation Services, 2010).

The process of shaping of personalization of character can be accure by many factors, there are derive from; such as heredity, millieu, human interaction, education etc (Mary, 2006). As ametter of fact a personality as a result of internalization of norm or virtues, use to develope the way of thinking, point of view, action and attitude. The virtues consist on a number of values, moral and norm, like honest, able to do something for other in social life, amiable, believeble and appreciate others. Interaction among people can develop human character or personality in community that will be a nation character. Therefore to the develope nation character by develope individual character. One of the aspects that cruciently for educational character and nation culture moral development. Futher more, the crucial aspect in educational character and culture is moral development, some synonim concerning with moral; moral, ethic, moral behavior, morality and immorality (Cuttings Agber, 2015). It's necessary to explain by each other there are; moral come from latin that is 'mores' it means the way of people act, habit in a social group. Webster's New World Dictionary of American Language. Moral is capacity of some one to decide something true or wrong. Other meaning of moral also any behavior or action can besuitable by people in the community.

\section{Educational Character}

Educational Character is the basic of the whole personality development to attain the existency of individual with certain characteristics. Character is the personality that derive from the accumulated of norm that confirm of the process of internalization of norm or other virtues. IT believed as the point of view, the way of thinking, the way of attitude or acting, beliefableand appreciate other people. 
Cuture: As a whole of system thinking, value, moral, norm and believe of re used in human life conduct the social system, economy system, believe system, technology and scince system. (Puskur, Kemdiknas, 2010).

Hoppers (2006) Non Formal Education is one of the three sub system of National Education To day the government of Republic of Indonesia is more attention in using this sub system in maximal one, by using and developing all the components in hirarchies in the whole system in Non Formal Educational to cover the need of education to all of citizen.

Based on the essay above concerning with the meaning of character or personality, the development of community is a higher level is increasingly over the year, which is noted by economic development or get an oportunity to have agood education beside that people is able buy several product as the result of advancing sciene and technology like some kind of a tool in communication. So the social interaction in comunity is being intence, more over globalization is being intense to promote interaction among peole in the world.

No doutbly that fenomena will cause other impacts and problems to moral and behavior of people in community. It needed educational character and cuture must be given to the studen or implementation educational character in our educational system. Educational character and culture is meaning an education that can how to implay the moral, values, and culture on educational activities by using value system and cultural base on "Local Wisdom: The Value System of Minangkabau Ethnic Customs as A Fudamental Basic of Educational Character in Indonesia"(Mungmachon, 2012).

\section{Local Wisdom (Values and Customs of Minangkabau Culture)}

The appirance of Minangkabau people in the past, present (today), future is an atractive to be an illustration for study educational character base on values, customand culture of Minangkabau (Hastuti, Julianti, Erlangga, \& Oswari, 2013).

Minang people ls famous as religious have high dynamic with their culture "merantau" (habit to make a living in other country). Minang people like to work hard by himself, they have creactive by themself especially in bussines etc, they work hard ,last, discipline and long, their free to do something by himself not to be control or under command with other people (like kaki lima trade in Tanah Abang for example). Beside that there are many peole also work in government officials in many field. so that they are very creative be a leader in government and private. The appirance of Minang people is determined by the values system of Minang customs and culture, the values system of Minagkabau can be describe as follow;

\section{Basic Values of Minang Custom}

\section{Point of View for Life of Minang People}

Their opinion for life is to help other people is determine in their expression ("biduik bajaso, mati bapusako"). In the process of values always see one judgment of value, select an action. In the concept of values for life Minang people have to work hard to collect the material for the family member to fullfil their need (Munir, 2013). This is one of the values concept in nature of Minangkabau. Beside that Minangkabau trab they have point of view to think the next generation for sustenable life must have a suplier for the next generation, there for they work continiously in their life spain. 
Local Wisdom: The Values System of Minangkabau Ethnic Customs...

\section{Point of View for Work}

As well as that theway of life helping people, family, relativeor other people in community, so they must strugle for life to fulfil their commitment (Alifah, 2006). The result of work of making money can solve the problem the proverb say "bilang rono dek panyakik, bilang bangso tak ba ameb", it means that self esteem can be lost or going down if some one came from the poor. To over come the problem people must motivate themself to work hard for making money. This is a positive value for sustainable in the family and commuity.

\section{Point of View for Time}

In every day life we often hear "time is money" this statement it is not new because Minang people has hold this value into their life as the way of life. Minang people must think for the future earn the money for next generation of young people and what will be left (herritage) for them after died. The motto don't spend the time for un useful. This is an expression of Minang people for example "duduak marawik ranjau, tagak maninjau jarab".

\section{Point of fiew to the nature}

Minang people take a nature as a teacher the proverb says "alam takambang jadi guru", and other expression "panakiak pisau si rawik ambiak galab batang lintabuang. Salodang ambiak kanyiru satitiak jadikan lawik sakapa jadikan gunuang. Alam takambang jadi guru. Adek nan indak lapuak di hujan, nan indak lakang di paneh"; it means sum of the values system is constanly use for ever, and the others can change according to the need of people.

Minangkabau is a beautiful ceenary, high monotenous and river a beatiful nature with flora and fauna give many inspirations to make prosperity country, people are fine and amiable, can get along with other people in the country as a prosperous country .

\section{CONCLUSION}

Minangkabau is rich country especially in dealing with value system and culture a unic personality and beautiful performance of the people (Sukandi, 2014). Based on the essay a bove we can concluded that the values system and culture of Minangkabau can be used as an alternative in educational character.

\section{REFERENCES}

Alifah, A. (2006). Kepuasan Kerja. Bandung. Retrieved from http:/ / file.upi.edu/Direktori/FPEB/PRODI._MANAJEMEN_FPEB/1975070420 03121-ASKOLANI/Makalah_Kepuasan_Kerja.pdf

Centre for Strategy \& Evaluation Services. (2010). Evaluation of the Indicators of the Entrepreneurship and Innovation Programme. Kent. Retrieved from http://ec.europa.eu/cip/files/docs/eip_indicators_evaluation_finalreport_february 2010_en.pdf

Cuttings Agber, T. (2015). Tiv Traditional Religion and Its Contribution to the TradoEducational and Technological Development of the Tiv Society. Humanities and Social Sciences, 3(5), 215. https://doi.org/10.11648/j.hss.20150305.18 
Dronkers, J., Karsten, S., Velden, R. Van Der, Webbink, D., \& Werfhorst, H. Van De. (2011). Educational systems and four central functions of education. Educational Research, 1-18.

Hastuti, E., Julianti, D., Erlangga, D., \& Oswari, T. (2013). Local Wisdom Socio-Cultural of Minangkabau Society in Indonesia. The International Journal of Social Sciences, 17(1), 7579 .

Retrieved from http://erni.staff.gunadarma.ac.id/Publications/files/1952/International+Journal+T IJOSS+Erni+dkk.pdf

Hoppers, W. (2006). Non-formal Education and Basic Education Reform: A Conceptual Review. Paris: International Institute for Educational Planning. Retrieved from http://unesdoc.unesco.org/images/0014/001444/144423e.pdf CN - HOP 36

Mary, M. F. (2006). Generations of Traits (Module The Basics and Beyond: An Introduction to Heredity). Utah. Retrieved from https://learn.genetics.utah.edu/content/basics/activities/pdfs/TraitsGenerations.pdf

Minkler, M. (2012). Introduction to community organization and community building. Community Organizing and Community Building for Health and Welfare, 5-26.

Mungmachon, M. R. (2012). Knowledge and Local Wisdom : Community Treasure. International Journal of Humanities and Social Science, 2(13), 174-181.

Munir, M. (2013). Hidup di Rantau Dengan Damai: Nilai-Nilai Kehidupan Orang Minangkabau dalam Menyesuaikan Diri dengan Lingkungan Budaya Baru. In Prosiding The 5th International Conference on Indonesian Studies: "Ethnicity and Globalization" (pp. 27-41). Depok: Fakultas Ilmu Budaya Universitas Indonesia.

Sukandi, S. S. (2014). First Language Interferences on Minangkabau-Indonesian EFL Students' Linguistic Repertoire in the Process of Advancing Their Multilingual Awareness. In International Seminar on English Language and Teaching (ISELT) "Literacy and Competency of EFL Learning in the 21st Century". Padang: UNP Press. Retrieved from http:/ / ejournal.unp.ac.id/index.php/selt/article/download/6739/5279

Tchuente, M. (2006). Globalization, Science and Technology : Challenges and Opportunities for SubSabaran Africa. Tokyo. Retrieved from http://archive.unu.edu/globalization/2006/files/Tchuente_Conference_Japan_07_ 06.pdf 